\title{
THE ACTIVE LEARNING ATTRIBUTES AND EMPLOYABILITY READINESS AMONG ENGINEERING GRADUATES IN THE HIGH EDUCATION INSTITUTES IN OMAN
}

\author{
Masoud Rashid Al Hinai \\ PhD Research Fellow \\ Faculty of Business and Accountancy \\ University of Selangor \\ 40000 Shah Alam, Selangor Darul Ehsan, Malaysia \\ E-mail: alhinai6602@gmail.com \\ Dr. Abul Bashar Bhuiyan \\ Associate Professor \\ Faculty of Business and Accountancy \\ University of Selangor \\ 40000 Shah Alam, Selangor Darul Ehsan, Malaysia \\ E-mail: bashariuk@gmail.com \\ Dr. Nor Azilah Husin \\ Associate Professor \& Deputy Dean \\ Faculty of Business and Accountancy \\ University of Selangor \\ 40000 Shah Alam, Selangor Darul Ehsan, Malaysia \\ E-mail: nor_azilah@unisel.edu.my
}

\begin{abstract}
The aim of this study is to investigate the effects of Active Learning attributes on the employability readiness of the engineering graduates of the High Education Institutes in Oman. The study adopted self-directed structured questionnaire was distributed to a sample of engineering students and graduates from a number of colleges and universities. The study used the structural equation modelling (SEM) for analysed the collected data. The findings of the study reveal that universities active learning facilities have high positive attribution for promoting team work skills, learning in safe working environment, endorsing adaptability skills, and developing analytical thinking abilities among graduates. However, the findings of the study indicate that HEIs are requested to effectively utilise active learning facilities to promote the attainment of technical skills, development of lifelong learning skills especially the openness to new ideas and the drive to use new technologies, endorsement of problem-solving skills, and the engagement and the development of graduates' intrinsic motivation to improve their graduates' Readiness for Employability. Specifically, study findings showed Active Learning attributes factor could have high influence on the Readiness for Employability of the graduates in Oman when they are utilised effectively. Finally, the study's implementations and recommendations
\end{abstract}


could be transferred to the Gulf and Arab or other countries' contexts having similar settings of $H E$ systems and similar issues of skills gap and employability concern of their graduates.

Keywords: Active Learning Attributes, Employability Readiness, Engineering Graduates, High Education Institutes \& Oman.

\section{INTRODUCTION}

The research of graduate readiness for employability is considered as a new concept in Oman and other Gulf countries. Despite the fact that youth unemployment is a major concern shared by many countries, few number of studies have focused on youth impression of their readiness for employability (Salehi-Isfahani, 2016; States, 2008). One research which analyzed BMA employability in Oman called for better communication between work providers and HEIs to align curricula with industries requirements to close the skills gap of graduates of the HE systems (Al-Azri, 2016) . Though, there were some studies that highlighted the effect of higher education on graduates' skills attainment to improve their readiness for employability. However, there has been no such graduate readiness for employability framework developed and used to analyze the readiness for employability of engineering graduates in the country. A recent study on the engineering readiness for employability of the Higher Education Institutes (HEIs) in Oman has specified five factors that affect graduates' readiness for employability (Al Hinai, Bhuiyan, \& Husin, 2020a, 2020b, 2020c; Rahman \& Bhuiyan, 2019). Those factors are human capital, social capital, Individual, Institution-Related, and Active Learning attributes. This new readiness for employability frame work was developed from the higher integrated frame work (Clarke, 2018). By using this graduates' readiness for employability framework, Ministry of higher education, HEIs, OAAA, academia as well as employers will be able to identify the shortfalls of the attained employability skills of the graduates and identify the possible direct factors causing such gap. This framework will be a milestone tool for HEIs to enhance their understanding of variables that affect their graduates' readiness for employability. The graduate readiness for employability framework will assist the higher educational providers, especially engineering colleges, in Oman as specific and other GCC countries to understand the influencing graduate attributes factors which affect graduate readiness for employability and as a result improve the quality of engineering education which consequently, will enable the engineering colleges to produce graduates suitable for employment. Specifically, the aim of this paper is to determine the effect of Active Learning attributes factors on the graduates' readiness for employability to improve the quality of engineering education of the HEIs in Oman which consequently, will enable the engineering colleges to produce graduates suitable for employment. More specifically, this study aims to answer the following question, how significant are the contributions of the Active Learning attributes factors on the Readiness for Employability among the engineering graduates of the HEIs in Oman? Therefore, the aim of this study is to investigate the effects of Active Learning attributes on the employability readiness of the engineering graduates of the High Education Institutes in Oman.

\section{LITERATURE REVIEW}

Active Learning Attributes consisting of Computer Based Training (CBT), Simulators, and Virtual Learning Equipment (VLE) are considered as interactive learning environment. They are close resemblance of real-world environments. This equipment uses a high-fidelity virtual environment to enhance learning. The use of active lab environment is relatively new method 
and therefore, its suitability must be investigated as an adequate tool in delivering transferable training skills (Adams et al., 2008; Fitzgerald et al., 2011). Other researcher has pointed out that the workplace environment, and the use of hypermedia technologies are valuable sources for workers and students training (Conrad, 2008). Also, active labs environment has positive learning attributes (Bills, 2009). This latest study had found a number of benefits can be gained from interactive simulations such as the simulation of real-world scenarios in a very safe simulated live virtual environment. Besides, they can provide easy understanding of complex systems and enhance the critical thinking skills required when working virtually in a resemblance to dangerous work environment situations.

Besides, the interactive simulations with the aim to improve learning retention in knowledge-based online training courses was investigated to analyse the effectiveness of online interactive simulations in the improvement in learners' ability to apply critical thinking skills in a dangerous work environment. This study found that the implementation of interactive simulation was as effective as training in real live equipment (Boyd, 2017). Also, in a study for analysing the importance of active learning in teaching practical competencies to enhance the quality of engineering graduates for their readiness of employability, it stated the importance of online learning, blended learning, collaborative learning, laboratory learning and interactive learning. Also computer programs, Computer Based Training (CBTs), Virtual Learning Environment (VLE) and simulators are important as well (Hassan \& Puteh, 2017).

Additionally, to enhance the importance of the use and the implementation of active learning facilities to equip engineering graduates with employability competencies, one study analysed the strategies of addressing the idea of "Design Thinking" in the curriculum of engineering programmes of HEIs. It recommended the utilisation of virtual reality environment technologies to fulfil the requirement of actual needs and visualize close to reality design solutions of new ideas and technologies. Also it suggested the use of basic design tools such as essential thinking, creative problem solving and emulation and simulation concepts (Shetty \& $\mathrm{Xu}, 2018)$.

Moreover, in a study of the new employable required skills for the future as the fourth industrial revolution is commencing, the founded required skills were listed to include Analytical thinking and innovation, Active learning and learning strategies, Creativity, Originality and initiative, Technology design and programming, Critical thinking and analysis, Complex problem solving, Leadership and social influence, Emotional intelligence, Reasoning, Problem solving and ideation, and System analysis and evaluation (Kamaruzaman, Hamid, Mutalib, \& Rasul, 2019). Such skills emphasized the importance of implementing of active learning equipment and environment.

Also, in a study of the Critical Analysis on Employment of Graduates in Oman, three objectives consisting of the problems confronted by graduates in getting work placement, the problems facing the employers with the outcomes of the current HE system, and the methods to be endorsed to improve the graduates of the HE system to increase job attainment for Omanis were analysed. The findings of the study revealed that graduates lacked the technical abilities including design, testing, and configuration management, personal skills such as communication and teamwork, and professional qualities. Also, the study illustrated that problems facing the students getting work placement were due to their English language proficiency, communication skills, weakness of understanding basic concepts, and the skills gap between education and employability requirements. The study recommended improving the alignment between the academic curricula and the essential required employability skills, enriching the students' 
projects to be essential parts of the learning mechanism, and enhancing the use and implementation of virtual training (Edwin \& Sabura, 2019).

Finally, a recent study on the engineering readiness for employability of the Higher Education Institutes (HEIs) in Oman has specified five factors that affect graduates' readiness for employability (Al Hinai et al., 2020b). Those factors are human capital, social capital, Individual, Institution-Related, and Active Learning attributes. Hence the aim this study will focus on analysing the effectiveness of implemnting active learning equipment and environment on the Readiness for Employability among Engineering graduates of the HEIs in Oman.

The initial theoretical framework representing the relationship among the study variables is presented in figure 1. This portion of the framework is obtained from a wider study of factors affecting the Readiness for employability among Engineering graduates of the HEIs in Oman (Al Hinai et al., 2020b).

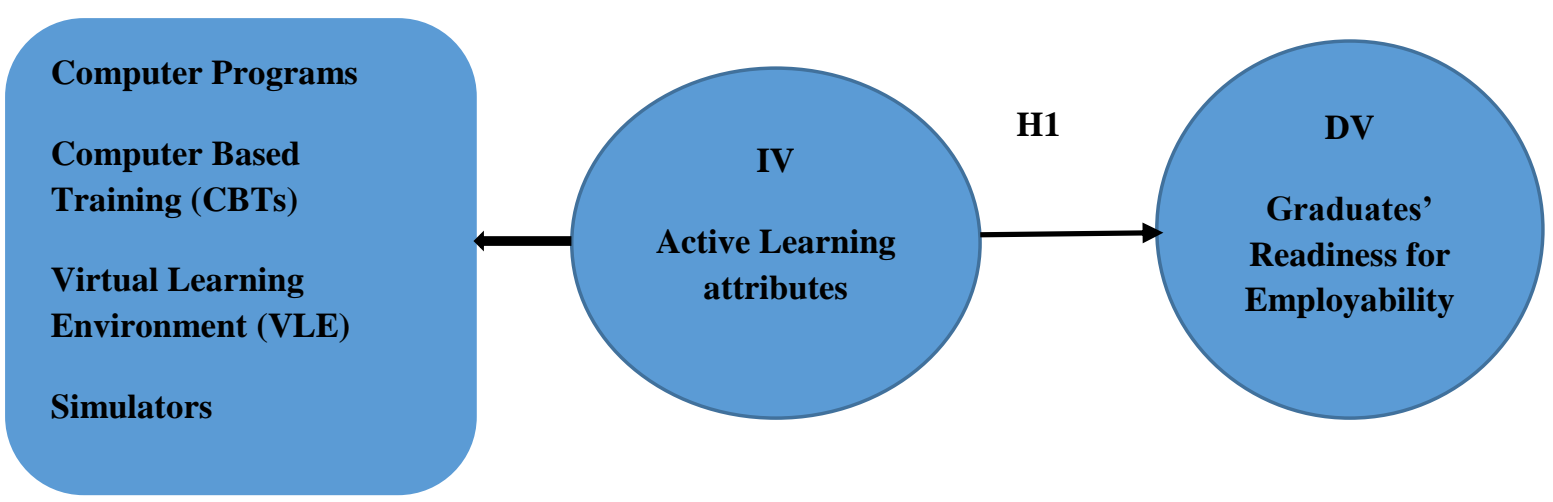

Figure 1. The influence of Active Learning Attributes on Graduates' Readiness for Employability among Engineering graduates of the HEIs in Oman

\section{H1: There is a significant relationship between Active Learning attributes and graduate's readiness for employability among engineering graduates of the HEIs in Oman.}

\section{METHODOLOGY}

The simple random characteristic strategy of the sampling technique was utilised by collecting data from an intended sample consisting from 340 random sample of engineering students obtained from different HEIs in Oman. To ensure the validity and clarity of the questionnaires, a panel of experts were consulted consisting of two academic engineering experts and two language experts. The findings of this study are accomplished utilizing the quantitative statistical methodology approach. This approach implements a numerical analysis using survey questionnaires as the base to collect data from students, and graduates (Creswell \& Creswell, 2017; Dörnyei, 2007).

Human Capital Theory were utilised as the underpinning theory of the study since it examines the financial benefits resulting from the investments in people' skills and resources. Such investment will result to have highly-skilled labors placed in highly-skilled careers, which could improve the nation's economy and prosperity (Becker, 1962; Leslie \& Brinkman, 1988; McMahon, 2009; Schultz, 1963; Slaughter, Taylor, \& Rosinger, 2015). 
Also, the motivation theory is added as another underpinning theory of the study because of its application to interactive simulations which is one of the graduates' attributes factors of the study. There are two types of motivation related to interactive simulation. Extrinsic motivation and intrinsic motivation. The later one applies to our study. It is described as the type of activity or behaviour which the student engaged with to reach the required accomplishment (Kapp, 2012). Therefore, intrinsic motivation encourage learning and accomplishment as the students involve themselves in interactive educational simulations activities as adult adapt motivational learning transitions (Knowles, Holton III, \& Swanson, 2012) .

Other studies of interactive simulations found them to provide non-cognitive and essential skills, besides the motivational benefits due to the simulation activities (Boyd, 2017; Chow, Woodford, \& Maes, 2011; Tennyson \& Jorczak, 2008). Another important finding is noted by Driscoll (2005) who expressed that motivation is accomplished when students successfully reached the objectives of the current learning goal, and are motivated to select and engage into additional learning activities. Therefore, correctly created interactive simulations activities are created to motivate students to progress and set new objectives or learning outcomes as they engage through the simulation procedures (Driscoll, 2005) .

Also, two statistical programs are used for data analysis. The first one is the use of the Statistical Package for the Social Studies (SPSS) version 26.0 to administer the preliminary data analysis. The second statistical program utilised for this study was the Partial Least Square Structural Equation Modelling (PLS-SEM) software. This program is used for the evaluation of the reflective measurement model, structural model, path analysis, and hypotheses testing (Hair Jr, Sarstedt, Ringle, \& Gudergan, 2017).

\section{Testing for Normality}

\section{DISCUSSION OF RESEARCH QUESTIONS AND FINDINGS}

The descriptive statistics present the statistical distribution of the study data that includes the observed variables, the means, standard deviations, skewness, and kurtosis. The SPSS 26 version software was used to provide the descriptive statistics which highlights the statistical distribution of the collected data of the sampled pilot test. This statistical data represents the study assigned variables, the means and the standard deviations. In addition, skewness, and kurtosis are employed for testing the normality of the data. Table 1 show the results of the descriptive statistics calculation and testing the normality of the data. As shown in the tables, all selected variables have skewness values as well as kurtosis values within the range -3 and +3 which signify that the study variables are normally distributed. Specifically, the recommended values for skewness are between 3 and +3 , and the values for kurtosis are between -10 to +10 when using SEM (Urbano, 2013).

Table 1. The skewness and kurtosis for normality

\begin{tabular}{|c|c|c|c|c|c|c|}
\hline \multirow{3}{*}{$\begin{array}{c}\text { Active } \\
\text { Learning } \\
\text { attributes }\end{array}$} & \multicolumn{5}{|c|}{ Descriptive Statistics } & \multirow{3}{*}{$\begin{array}{l}\text { Normality } \\
\text { assumption }\end{array}$} \\
\hline & $\mathrm{N}$ & \multicolumn{2}{|c|}{ Skewness } & \multicolumn{2}{|c|}{ Kurtosis } & \\
\hline & Statistic & Statistic & Std. Error & Statistic & Std. Error & \\
\hline ALA1 & 340 & -.515 & .132 & .125 & .264 & Normal \\
\hline ALA2 & 340 & -.453 & .132 & .076 & .264 & Normal \\
\hline ALA3 & 340 & -.409 & .132 & -.354 & .264 & Normal \\
\hline
\end{tabular}




\begin{tabular}{lllllll}
\hline ALA4 & 340 & -.460 & .132 & .178 & .264 & Normal \\
ALA5 & 340 & -.442 & .132 & -.169 & .264 & Normal \\
ALA6 & 340 & -.404 & .132 & -.101 & .264 & Normal \\
ALA7 & 340 & -.372 & .132 & -.119 & .264 & Normal \\
ALA8 & 340 & -.443 & .132 & -.389 & .264 & Normal \\
ALA9 & 340 & -.317 & .132 & -.186 & .264 & Normal \\
ALA10 & 340 & -.684 & .132 & .422 & .264 & Normal \\
\hline
\end{tabular}

Table 2. Mean and standard deviation-Active Learning Attributes

\section{Descriptive Statistics-Active learning Attributes}

Std.

Item $\quad$ N Mean Deviation

\begin{tabular}{llll}
\hline The university active learning facilities were well enough to endorse & 340 & 5.1147 & 1.28358
\end{tabular} developing of team working skills

The university active learning facilities were well enough to endorse $340 \quad 5.0676 \quad 1.29150$

learning in a Safe Working Environment

The university active learning facilities were well enough to endorse $340 \quad 4.9324 \quad 1.29150$

developing of adaptability skills

The university active learning facilities were well enough to endorse $340 \quad 4.9059 \quad 1.25389$

developing of analytical thinking abilities

The university active learning facilities were well enough to endorse $\quad \begin{array}{lll}340 & 4.8588 & 1.32507\end{array}$

developing of technical skills and abilities

The university active learning facilities were well enough to $\quad \begin{array}{llll}340 & 4.8353 & 1.38340\end{array}$

encourage development of lifelong learning skills including

openness to new ideas and a drive to use new technologies

$\begin{array}{llll}\begin{array}{l}\text { The university active learning facilities were well enough to endorse } \\ \text { developing of Problem-solving skills }\end{array} & 4.7941 & 1.38213\end{array}$

The university active learning facilities were well enough to endorse $340 \quad 4.7735 \quad 1.35842$

developing of engagements and intrinsic motivations

The university active learning facilities were well enough to $\quad \begin{array}{llll}340 & 4.6324 & 1.52757\end{array}$

contextualization of learning, manifested through greater transfer to

a corresponding real environment

$\begin{array}{lllll}\text { The university active learning facilities were well enough to } & 340 & 4.5912 & 1.37848\end{array}$

encourage richer and/or more creative thinking to develop

appropriate solutions

Active Learning Attributes Average Score

$340 \quad 4.9000 \quad 1.18819$

Note; using 7-dimensional Likert scale where 1 represents "strongly disagree", and 7 represents "strongly agree"

Table 2 reveals that universities active learning facilities have high positive attribution for promoting team work skills, learning in safe working environment (Bills, 2009), endorsing adaptability skills, and developing analytical thinking abilities among graduates (Boyd, 2017). That readiness for employability skills scored higher than the active learning attributes average score of 4.9. They scored 5.1147, 5.0676, 4.9324, and 4.9059 respectively. HEIs are requested to utilise those active learning facilities to promote the attainment of technical skills, 
development of lifelong learning skills especially the openness to new ideas and the drive to use new technologies, endorsement of problem-solving skills, and the engagement and the development of graduates' intrinsic motivation (Shetty \& Xu, 2018).

Table 3. Summary of measurement model findings

\begin{tabular}{llccccc}
\hline $\begin{array}{l}\text { Constructs } \\
\text { (Latent } \\
\text { Variable) }\end{array}$ & $\begin{array}{l}\text { Measurement } \\
\text { items } \\
\text { (Indicators) }\end{array}$ & $\begin{array}{c}\text { Convergent } \\
\text { Validity } \\
\text { (Loading) }\end{array}$ & $\begin{array}{c}\text { Internal } \\
\text { Consistency } \\
\text { Reliability } \\
\text { CA }\end{array}$ & $\begin{array}{c}\text { Composite } \\
\text { Reliability }\end{array}$ & CR & $\begin{array}{c}\text { Discrimin } \\
\text { ant } \\
\text { Analysis }\end{array}$ \\
\hline $\begin{array}{l}\text { Active } \\
\text { Learning }\end{array}$ & ALA1 & 0.857 & 0.962 & 0.967 & 0.748 & Yes \\
Attributes & ALA2 & 0.866 & & & & \\
& ALA3 & 0.847 & & & & \\
& ALA4 & 0.879 & & & \\
& ALA5 & 0.899 & & & \\
& ALA6 & 0.882 & & & \\
& ALA7 & 0.900 & & & \\
& ALA8 & 0.830 & & & \\
& ALA9 & 0.881 & & & \\
& ALA10 & 0.802 & & & \\
\end{tabular}

By utilising SEM-PLS 3.0 (Hair Jr et al., 2017), table 3 highlights a brief summary of the results obtained for the measurement model assessment which illustrates that the reliability and validity tests for this study. The findings show that all the requirements of reliability and validity of the measurement model assessment are met.

\section{Hypothesis Testing}

To conduct the hypotheses testing connected to the structural model of the study, there are several elements are required to be considered. The first element, for a hypothesis to be valid, the value of the path coefficient of 0.1 or higher is required to account for a certain impact within the model (Hair, Ringle, \& Sarstedt, 2011). Secondly, the acceptable t-value and p-value must be greater than 1.96 and less than 0.05 respectively (Ramayah, Cheah, Chuah, Ting, \& Memon, 2018). The hypothesis testing result of the impact of Institution-Related Attributes on the Readiness for Employability is illustrated in table 4.

Table 4. Hypothesis testing results

\begin{tabular}{|c|c|c|c|c|c|c|}
\hline & $\begin{array}{c}\text { Path } \\
\text { Coefficient } \\
\beta\end{array}$ & $\begin{array}{c}\mathrm{T} \\
\text { Statistics }\end{array}$ & $\begin{array}{c}\mathrm{P} \\
\text { Values }\end{array}$ & $\begin{array}{c}5 \% \\
\text { BCI } \\
\text { LL }\end{array}$ & $\begin{array}{l}95 \% \\
\text { BCI } \\
\text { UL }\end{array}$ & $\begin{array}{c}\text { Decision } \\
(\mathrm{p}< \\
0.05)\end{array}$ \\
\hline $\begin{array}{l}\text { Active Learning Attributes -> } \\
\text { Readiness for Employability }\end{array}$ & 0.007 & 0.091 & 0.464 & 0.107 & 0.129 & Rejected \\
\hline
\end{tabular}

It is interesting to note that the graduates' attributes factor of Active Learning attribute (H1) showed no significance influence on the Readiness for employability of the Engineering 
graduates of the HEIs in Oman despite the importance of implementing virtual learning environment, CBTs, and simulation to enhance both technical and non-technical training for Engineering in a healthy and safe environment (Hassan \& Puteh, 2017). Also, Edwin \& Sabura (2019) stressed in the importance of conducting practical activities and students Projects utilizing virtual training as an essential part of the learning process. Besides, Shetty and Xu (2018), who addressed the importance of "Design Thinking" Strategies in Engineering Curriculum, Boyd (2017), who concluded the importance of Interactive simulations to improve learning recognition in knowledge-based virtual training courses. Also, Valdez et al., (2012), the importance of Virtual reality was analyzed and found as an essential lab tool environment to enhance Engineering training (Valdez, Ferreira, \& Barbosa, 2012). As a result, HEIs in Oman should invest heavily in the use and utilization of active learning as part of its future plan to develop its Engineering training to meet delivering future fourth industrial revolution required skills and improve the acquisition of the Readiness for Employability skills of its graduates.

\section{CONCLUSION AND POLICY RECOMMENDATION}

This study has shown that specific engineering factors such as the implementation of Active Learning attributes can be considered as an adequate independent variable in examining the graduates' Readiness for Employability of the engineering graduates of the HEIs in Oman. Though, the empirical evidence illustrates it does not influence the graduates Readiness for Employability significantly, however, its use is justified because Engineering use and implement interactive learning resources widely to simulate training and depicts real life engineering scenarios especially at the virtue of the $4^{\text {th }}$ industrial revolution era. The empirical implication for the utilisation of Active Learning contribute to the study due to the importance of active learning, simulation, and virtual reality for engineers to acquire engineering employability skills and competencies in a safe and healthy environment.

In conclusion, the findings of this study reveal that universities active learning facilities have high positive attribution for promoting team work skills, learning in safe working environment, endorsing adaptability skills, and developing analytical thinking abilities among graduates. However, the findings of the study indicate that HEIs are requested to effectively utilise active learning facilities to promote the attainment of technical skills, development of lifelong learning skills especially the openness to new ideas and the drive to use new technologies, endorsement of problem-solving skills, and the engagement and the development of graduates' intrinsic motivation to improve their graduates' Readiness for Employability. Specifically, the Active Learning attributes can be made as a significant attribute factor by widening the implementation of virtual learning environment, CBTs, and simulation to enhance both technical and non-technical training for Engineering in a healthy and safe environment. According to human capital theory (HCT), when implementing the study discussed reforms, the quality of the graduates of the HEIs will be improved so that skills, competent and ready for employability engineering graduates will be produced, and the mission of the HE system will be accomplished leading to high employability rate among graduates and high economic growth. More sspecifically, study findings showed Active Learning attributes factor could have high influence on the Readiness for Employability of the graduates in Oman when they are utilised effectively. Finally, the study's implementations and recommendations could be transferred to the Gulf and Arab or other countries' contexts having similar settings of HE systems and similar issues of skills gap and employability concern of their graduates. 


\section{REFERENCES}

Adams, W. K., Reid, S., LeMaster, R., McKagan, S. B., Perkins, K. K., Dubson, M., \& Wieman, C. E. (2008). A study of educational simulations part I-Engagement and learning. Journal of Interactive Learning Research, 19(3), 397-419.

Al-Azri, A. K. H. (2016). Academics', students', employers', and graduates' perceptions towards business management and administration undergraduate employability: implications for higher education and industry in Oman. Brunel University London,

Al Hinai, M. R., Bhuiyan, A. B., \& Husin, N. A. (2020a). AN EMPIRICAL REVIEW ON THE GRADUATE ATTRIBUTES AND READINESS FOR EMPLOYABILITY AMONG THE ENGINEERING GRADUATES IN THE HIGHER EDUCATION INSTITUTIONS (HEIs). Indian Journal of Finance and Banking, 4(3), 8-25.

Al Hinai, M. R., Bhuiyan, A. B., \& Husin, N. A. (2020b). THE MODERATING EFFECTS OF GENDER, CAREER, MORAL MINDSET ON THE RELATIONSHIP BETWEEN THE GRADUATE ATTRIBUTES AND READINESS FOR EMPLOYABILITY AMONG ENGINEERING COLLEGES GRADUATES IN OMAN. International Journal of Accounting \& Finance Review, 5(3), 16-30.

Al Hinai, M. R., Bhuiyan, A. B., \& Husin, N. A. (2020c). Theoretical Review on The Graduate Attributes and The Readiness for Employability Among Engineering Graduates in The Higher Education Institutes (HEIs) in Oman. Indian Journal of Finance and Banking, 4(2), 130-139.

Becker, G. S. (1962). Investment in human capital: A theoretical analysis. Journal of political economy, 70(5, Part 2), 9-49.

Bills, C. G. (2009). High engagement strategies in simulation and gaming. Handbook of Improving Performance in the Workplace: Volumes 1-3, 395-434.

Boyd, J. L. (2017). Interactive simulations: Improving learning retention in knowledge-based online training courses. Capella University,

Chow, A. F., Woodford, K. C., \& Maes, J. (2011). Deal or No Deal: using games to improve student learning, retention and decision-making. International journal of mathematical education in science and technology, 42(2), 259-264.

Clarke, M. (2018). Rethinking graduate employability: The role of capital, individual attributes and context. Studies in Higher Education, 43(11), 1923-1937.

Conrad, D. L. (2008). From community to community of practice: Exploring the connection of online learners to informal learning in the workplace. The Amer. Jrnl. of Distance Education, 22(1), 3-23.

Creswell, J. W., \& Creswell, J. D. (2017). Research design: Qualitative, quantitative, and mixed methods approaches: Sage publications.

Dörnyei, Z. (2007). Research methods in applied linguistics: Quantitative, qualitative, and mixed methodologies: Oxford University Press Oxford.

Driscoll, M. P. (2005). Psychology of learning for instruction.

Edwin, M. M. D., \& Sabura, F. M. (2019). Critical Analysis on Employment of Graduates in Oman.

Fitzgerald, G., Mitchem, K., Hollingsead, C., Miller, K., Koury, K., \& Tsai, H.-H. (2011). Exploring the bridge from multimedia cases to classrooms: Evidence of transfer. Journal of Special Education Technology, 26(2), 23-38.

Hair, J. F., Ringle, C. M., \& Sarstedt, M. (2011). PLS-SEM: Indeed a silver bullet. Journal of Marketing theory and Practice, 19(2), 139-152. 
Hair Jr, J. F., Sarstedt, M., Ringle, C. M., \& Gudergan, S. P. (2017). Advanced issues in partial least squares structural equation modeling: saGe publications.

Hassan, N. F., \& Puteh, S. (2017). A Survey of Technology Enabled Active Learning in Teaching and Learning Practices to Enhance the Quality of Engineering Students. Advanced Science Letters, 23(2), 1104-1108.

Kamaruzaman, F. M., Hamid, R., Mutalib, A. A., \& Rasul, M. S. (2019). Conceptual framework for the development of 4IR skills for engineering graduates. Global Journal of Engineering Education, 21(1), 54-61.

Kapp, K. M. (2012). The gamification of learning and instruction: Wiley San Francisco.

Knowles, M. S., Holton III, E. F., \& Swanson, R. A. (2012). The adult learner: Routledge.

Leslie, L. L., \& Brinkman, P. T. (1988). The Economic Value of Higher Education. American Council on Education/Macmillan Series on Higher Education: ERIC.

McMahon, W. W. (2009). Higher learning, greater good: The private and social benefits of higher education: JHU Press.

Rahman, M. Z., \& Bhuiyan, A. B. (2019). The Influencing Factors on the Effectiveness of Foundation Training Programs: A Case Study of the Health Cadre Service in Bangladesh. International Journal of Business and Management Future, 3(2), 13-21.

Ramayah, T., Cheah, J., Chuah, F., Ting, H., \& Memon, M. (2018). Partial least squares structural equation modeling (PLS-SEM) using smartPLS 3.0. In An Updated Guide and Practical Guide to Statistical Analysis: Pearson.

Salehi-Isfahani, D. (2016). Human Development in the Middle East and North Africa: Springer.

Schultz, T. (1963). The Economics Value of Education . New York and London. Columbia. In: University Press.

Shetty, D., \& Xu, J. (2018). Strategies to Address "Design Thinking” in Engineering Curriculum. Paper presented at the ASME 2018 International Mechanical Engineering Congress and Exposition.

Slaughter, S., Taylor, B. J., \& Rosinger, K. O. (2015). A critical reframing of human capital theory in US higher education. Critical approaches to the study of higher education: A practical introduction, 80-102.

States, U. N. D. P. R. B. f. A. (2008). Arab Human Development Report 2009: Challenges to Human Security in the Arab Countries (Vol. 5): United Nations Publications.

Tennyson, R., \& Jorczak, R. (2008). A Conceptual Framework for the Empirical Study of Instructional Games. HF O'Neill, RS Perez (eds.) Computer Games and Team and Individual Learning. In: Amsterdam, Boston, Heidelberg: Elsevier.

Urbano, R. C. (2013). Using secondary datasets to understand persons with developmental disabilities and their families: Academic Press.

Valdez, M. T., Ferreira, C. M., \& Barbosa, F. M. (2012). Virtual reality prototype as a tool in a lab environment.

\section{Copyrights}

Copyright for this article is retained by the author(s), with first publication rights granted to the journal. This is an open-access article distributed under the terms and conditions of the Creative Commons Attribution license (https://creativecommons.org/licenses/by/4.0) 